\title{
Developmental Physiology Differentiation/Growth
}

National Cancer Institute

\section{Source}

National Cancer Institute. Developmental Physiology Differentiation/Growth. NCI

Thesaurus. Code C18736.

The branch of physiology concerned with the changes that take place between fertilization and maturity. 